Далиборка Р. Поповић Државни универзитет у Новом Пазару Департман за филозофске науке

Душан П. Ристановић

Универзитет у Крагујевцу

Факултет педагошких наука у Јагодини

Катедра за дидактичко-методичке науке
УДК: 37.014.3(497.11)

https://doi.org/10.18485/uzdanica.2020.17.2.19

Прегледни рад

Примљен: 31. август 2020.

Прихваћен: 21. децембар 2020.

\title{
ПОТЕНЦИЈАЛИ ПРОЈЕКТНЕ НАСТАВЕ ЗА РАЗВИЈАҢЕ МЕЂУПРЕДМЕТНИХ КОМПЕТЕНЦИЈА
}

$A \bar{u} c \bar{u} p a \kappa \bar{u}:$ Један од кључних циљева савремених образовних политика односи се на неопходност развијања способности ученика које ће им омогућити функционисање у условима динамичних друштвених и технолошких промена. Потребан услов за остваривање овако дефинисаног циља је напуштање традиционалног, трансмисивно заснованог приступа настави и учењу и увођење ангажованијег процеса конструкције знања у реалном животном окружењу. Другачији приступ настави и учењу подразумева свеобухватну реформу образовног система, која би требало да се одвија у два кључна правца. Први се односи на курикуларну реформу, то јест на увођење курикулума оријентисаног на стицање и развијање кључних компетенција за целоживотно учење и, посебно, међупредметних компетенција. Други правац је усмерен на разматрање и примену различитих наставних стратегија и модела у школској пракси, који иду у сусрет наведеном концепту. С обзиром на то да је у наш школски систем од скоро уведена пројектна настава као обавезан модел рада, циљ овог рада је да се представе њене најзначајније могућности за развијање међупредметних компетенција ученика. У раду се полази од прегледа осам кључних компетенција за целоживотно учење дефинисаних од стране Европске комисије, а које су од 2017. године укључене и у систем образовања и васпитања Републике Србије. Након тога, издвојени су и предочени неопходност и значај развијања међупредметних компетенција код ученика, а затим је нагласак стављен на анализу могућности које пројектна настава може да пружи у том процесу. У закључку су апострофиране вредности пројектне наставе и добити како за ученике и наставнике, тако и за друштво у целини, у чему се огледају и педагошке импликације, јер представљају својеврстан позив наставницима за њену озбиљнију примену у школској пракси.

Кључне речи: кључне компетенције за целоживотно учење, међупредметне компетенције, пројектна настава.

\section{УВОД}

Све је уочљивије да велики број друштвених фактора детерминише промене и у образовном систему, посебно у смеру увођења парадигме учења која би омогућила развијање кључних компетенција за целоживотно учење. 
Основна функција ових компетенција огледа се у оснаживању појединаца за суочавање са реалним животним токовима, условљеним глобалним променама. Образовна политика, без обзира на континуирану тежњу унапређивања квалитета наставних програма и њихове реализације, тешко може предвидети све промене и образовне потребе које се дешавају захваљујући убрзаној динамици друштвених дешавања. Зато се од образовног система захтева потпуно другачији приступ и деловање у циљу развијања компетентне личности у професионалном, социјалном и личном погледу.

Промишљања ове врсте отварају питање која знања и умења треба усвојити, које практичне способности развијати, како би појединци успешно одговорили изазовима савременог доба. Према Слијепчевић и Зуковић (Слијепчевић, Зуковић 2015), то су она знања и умења која ће омогућити флексибилност и прилагодљивост појединца, јер је за опстанак у савременом друштву изузетно важна способност адаптације на новонастале ситуације. Тако је, на пример, у САД, на захтев политичара и привредника, развијен концепт „вештина за XXI век” (Pellegrino, Hilton 2012) који обухвата: a) когнитивни домен (подразумева компетенције као што су критичко мишљење, информациона писменост, расуђивање и аргументација, иновативност и др., груписане у кластере когнитивни процеси и стратегије, знање и креативност); б) интраперсонални домен (флексибилност, преузимање иницијативе, уважавање различитости, метакогниција, груписане у кластере интелектуална отвореност, радна етика и самоевалуација); в) интерперсонални домен (комуникација, сарадња, одговорност и решавање сукоба, груписане у кластере тимски рад и сарадња и лидерство). Слично, у Европској унији (Evropska komisija / EACEA / Eurydice, 2012) 2006. године дефинисано је осам кључних компетенција за целоживотно учење које укључују: комуникацију на матерњем језику, комуникацију на страним језицима, математичку компетенцију и основне компетенције из природних наука и технологије, дигиталну компетенцију, способност учења (учење учења), социјалне и грађанске компетенције, смисао за иницијативу и предузетништво и културолошку освешћеност и изражавање. Овако дефинисане компетенције представљају комбинацију знања, вештина и ставова неопходних за лично испуњење и развој, активно грађанство, социјалну укљученост и запошљавање. Узимајући у обзир друштвено-економске промене, резултате PISA студија и резултате јавних расправа, европски референтни оквир кључних компетенција за целоживотно учење је 2018. године ревидиран и ажуриран (Стојановић 2019). Сажети приказ оквира је приказан у табели 1. 
Поповић Р.Д.,Ристановић П. Д., Потенцијали пројектне...,;УЗДАНИЦА;2020, XVII/2;стр. 281-294

Табела 1. Кључне компетенције за целоживотно учење

\begin{tabular}{ll}
\hline Компетенције & Опис \\
\hline Компетенција писмености & Писменост је способност препознавања, разумевања, изражавања, \\
стварања и тумачења појмова, осећања, чињеница и мишљења \\
у усменом и писаном облику, користећи визуелне, звучне/аудио и \\
дигиталне материјале у различитим дисциплинама и контекстима. \\
Подразумева способност ефективне комуникације и повезивања \\
са другима на примерен и креативан начин. \\
Развој писмености чини основу за даље учење и даљу језичку \\
интеракцију. У зависности од контекста, компетенција писмености \\
може се развити на матерњем језику, језику школовања и/или \\
службеном језику у земљи или региону.
\end{tabular}

Вишејезична компетенција

Математичка компетенција и компетенције у природним наукама, технологији и инжењерству

Дигитална компетенција

Лична, социјална и компетенција за учење
Одређује способност одговарајуће и ефективне употребе различитих језика за комуникацију и обухвата исте главне вештине као и писменост. Компетенција интегрише историјску димензију и интеркултуралне компетенције. Ослања се на способност посредовања између различитих језика и медија, како је наведено у Заједничком европском референтном оквиру. По потреби, може укључивати одржавање и даље развијање компетенција матерњег језика, као и стицање званичног/званичних језика земље.

Математичка компетенција је способност да се развије и примени математичко мишљење у решавању низа проблема у свакодневним ситуацијама. Темељи се на добром савладавању рачуна, а нагласак је на процесу и активностима, као и на знању. Математичка компетенција у различитој мери укључује способност и спремност за употребу математичких начина размишљања и приказа (формуле, модели, конструкције, графикони, дијаграми).

Компетенција у природним наукама односи се на способност и спремност да се објасни природни свет коришћењем корпуса знања и методологије, укључујући посматрање и експериментисање, у циљу постављања питања и доношења закључака заснованих на доказима. Компетенције у технологији и инжењерству су примена тог знања и методологије као одговор на уочене људске жеље или потребе. Компетенције у науци, технологији и инжењерству укључују разумевање промена узрокованих људским деловањем и одговорност појединца као грађанина.

Укључује самоуверено, критичко и одговорно коришћење дигиталних технологија и њихово ангажовање за учење, на послу и за учешће у друштву. Укључује информатичку писменост и писменост у руковању подацима, комуникацију и сарадњу, медијску писменост, стварање дигиталног садржаја (укључујући програмирање), безбедност (укључујући дигиталну добробит и компетенције у вези са кибернетичком безбедношћу), питања везана за интелектуалну својину, решавање проблема и критичко мишљење.

Подразумева способност размишљања о себи, ефективног управљања временом и информацијама, сарадње са другима на конструктиван начин, задржавања отпорности (резилијентности) и управљања сопственим учењем и каријером. Укључује способност суочавања са несигурношћу и сложеношћу, учења како учити, подржавања сопственог физичког и емоционалног благостања, одржавања физичког и менталног здравља, вођења здравог и на будућност оријентисаног живота, као и способност емпатије и решавања сукоба у инклузивном и подржавајућем контексту. 


\begin{tabular}{|c|c|}
\hline Компетенције & Опис \\
\hline Грађанска компетенција & $\begin{array}{l}\text { Способност да се поступа као одговоран грађанин и да се у } \\
\text { потпуности учествује у грађанском и друштвеном животу, уз } \\
\text { разумевање друштвених, економских, правних и политичких } \\
\text { концепата и структура, као и глобалног развоја и одрживости. }\end{array}$ \\
\hline $\begin{array}{l}\text { Компетенција за } \\
\text { предузетништво }\end{array}$ & $\begin{array}{l}\text { Односи се на способност коришћења прилика и идеја и њихово } \\
\text { претварање у вредности за друге. Заснива се на креативности, } \\
\text { критичком размишљању и решавању проблема, преузимању } \\
\text { иницијативе и истрајности као и способности сарадње са другима } \\
\text { како би се планирало и управљало пројектима који имају културну, } \\
\text { друштвену или фринансијску вредност. }\end{array}$ \\
\hline $\begin{array}{l}\text { Компетенција културне свести и } \\
\text { изражавања }\end{array}$ & $\begin{array}{l}\text { Укључује разумевање и поштовање начина на који се идеје и } \\
\text { смисао креативно изражавају и преносе у различитим културама } \\
\text { и кроз низ уметности и других културних форми. Укључује } \\
\text { разумевање, развијање и изражавање сопствених идеја и осећај } \\
\text { за место или улогу у друштву на различите начине и у различитим } \\
\text { контекстима. }\end{array}$ \\
\hline
\end{tabular}

Компетенције које ученици треба да стекну у школи није могуће једном заувек дефинисати, јер се захтеви за њих непрестано мењају пред изазовима друштва. Такође, није их могуће развити све подједнако и у подједнакој мери код свих ученика. Ипак, важно је постојање листе компетенција као низа смерница за наставника који би их развијао у складу са потенцијалима ученика. Приказана листа кључних компетенција није хијерархијски организована, свака од њих је подједнако важна јер доприноси адаптацији на садашње време и блиску будућност и успешном животу у друштву знања.

Према подацима KeyCoNet-a, европске мреже образовних институција задужене за праћење и анализу имплементације кључних компетенција у основно и средње образовање, у многим земљама су спроведене или се спроводе реформе националних курикулума ради усклађивања са компетенцијским приступом (Arjomand et al. 2013). Са сличним циљем се спроводи и актуелна реформа система основног образовања и васпитања у Србији. Осам кључних компетенција за целоживотно учење укључено је у кровни закон којим се уређује систем предшколског, основног и средњег образовања Републике Србије ${ }^{1}$, а од школске 2018/19. године примењују се и нови програми наставе и учења, усмерени ка развоју компетенција.

Развијање наведених компетенција превазилази оквире традиционалног предметног курикулума и захтева оријентацију образовног процеса ка већој партиципацији ученика и интегрисању знања, вештина и ставова релевантних за различите реалне контексте. То имплицира неопходност примене истраживачки усмерених стратегија, модела и метода наставе, који се, у односу на традиционални модел, показују ефикаснијим у развијању кључних, а нарочито међупредметних компетенција. Један од таквих модела је пројект-

\footnotetext{
${ }^{1}$ Закон о основама систиема образовања и васииийања Рейублике Србије, 2017.
} 
на настава, па ће се у овом раду размотрити каква је њена улога као ресурса за развијање међупредметних компетенција.

\section{МЕЂУПРЕДМЕТНЕ КОМПЕТЕНЦИЈЕ У САВРЕМЕНОМ ОБРАЗОВАҢУ}

На кључним компетенцијама за целоживотно учење заснивају се и опште међупредметне компетенције, компетенције које се у школи развијају кроз наставу свих предмета, обухватају и ангажују школска знања на припреми ученика да буду конкурентни и функционални у садашњем и будућем образовном и професионалном простору и да компетентно и активно остварују своје грађанске улоге 2 Основно полазиште у развијању међупредметних компетенција јесте креирање адекватног окружења за учење које подразумева: стављање ученика пред проблем чије решавање захтева истовремену употребу предметних знања и међупредметних компетенција; реализацију наставних и ваннаставних активности у виду истраживачког учења; активности ученика које захтевају комбинацију индивидуалних и групних активности, како би се развијала лична, али истовремено и колективна одговорност; амбијентално учење, односно активно учествовање у животу локалне заједнице ${ }^{3}$ У табели 2 су приказане међупредметне компетенције за крај основног и средњег образовања у Републици Србији.

Табела 2. Преглед међупредметних компетенција за крај основног и средњег образовања у Републици Србији ${ }^{4}$

\begin{tabular}{ll}
\hline $\begin{array}{l}\text { Опште међупредметне компетенцие за крај } \\
\text { основног образовања и васпитања }\end{array}$ & $\begin{array}{l}\text { Опште међупредметне компетенције за крај } \\
\text { средњег образовања и васпитања }\end{array}$ \\
\hline Компетенције за учење & Компетенција за целоживотно учење \\
Одговорно учешће у демократском друштву & Комуникација \\
Естетичка компетенција & Рад са подацима и информацијама \\
Комуникација & Дигитална компетенција \\
Одговоран однос према околини & Решавање проблема \\
Одговоран однос према здрављу & Сарадња \\
Предузимљивост и предузетничке компетенције & Одговорно учешће у демократском друштву \\
Рад с подацима и информацијама & Одговоран однос према здрављу \\
Решавање проблема & Одговоран однос према околини \\
Сарадња & Естетичка компетенција \\
Дигитална компетенција & Предузимљивост и предузетничка компетенција \\
\hline
\end{tabular}

\footnotetext{
${ }^{2}$ Закон о основама систиема образовања и васииийања Рейублике Србије, 2017.

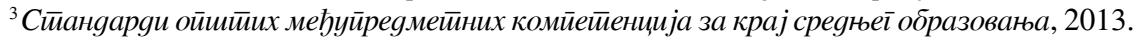

${ }_{4}^{4}$ Закон о основама систиема образовања и васииийана Рейублике Србије, 2017.
} 
Компарацијом приказаних међупредметних компетенција може се уочити идентичност у дефинисању, али другачији редослед у њиховом навођењу. Редослед је одређен зависно од дубине и начина њиховог могућег остваривања, као и од исхода које је могуће остварити на одређеном узрасту. Када је реч о значајности међупредметних компетенција, може се рећи да је подједнака, те је важно на систематичан начин подржати развијање сваке од њих. На старијем узрасту оне ће свакако, код већине ученика, бити развијене на комплекснијем нивоу.

Како је значај развијености међупредметних компетенција за будући живот младог човека велики (Burke 2005), пред образовни систем се поставља питање у којој мери и на које начине томе могу допринети наставници. Притом треба имати у виду додатну тешкоћу која проистиче из обимности програмских садржаја чијом реализацијом се доприноси остварености исхода учења и стандарда постигнућа. У сусрет разрешавању наведене дилеме, важно је нагласити да рад наставника и ученика на развијању међупредметних компетенција није конкурентан раду на садржајима и компетенцијама које су непосредно везане за одређене предмете. Напротив, развијене међупредметне компетенције представљају значајан потенцијал за разумевање наставних садржаја и њихову примену (Burke 2005, Freire 2001). У том смислу, значајно би било заједничко планирање интерактивних активности на нивоу школског програма, у чему се испољава иновативност и креативност наставника, али и аутономија школе у постизању васпитно-образовних исхода. Развијене међупредметне компетенције доприносе такође и интеграцији појединаца у различите социјалне контексте, уз изградњу аутономије у просуђивању и доношењу одлука (Burke 2005), што у значајној мери може утицати и на превенцију свих облика неприлагођеног понашања, посебно вршњачког насиља, односно на развијање емпатије, толеранције и интеркултуралности.

Сходно томе, долази се до проширивања листе са улогама наставника, у оквиру које се може издвојити значај сарадничке улоге за остваривање постављених васпитно-образовних циљева, са посебним освртом на развијање међупредметних компетенција. Новонастала парадигма учења од наставника захтева да традиционалну наставу замене формама које обезбеђују кохерентност плана и програма наставе и учења, а то подразумева интегрисање предметних садржаја како би се постигли дефинисани исходи учења. Тиме се стварају прилике у којима ученици имају могућност откривања и повезивања знања и искустава стечених у оквиру различитих предмета, учећи тако вештине које ће им користити у реалним, ваншколским животним ситуацијама. Неки аутори (Dart, Drake 1995) експлицитно истичу да тежиште наставе треба да се помера од знања која се уче у предметним дисциплинама, преко повезивања знања из различитих предмета, до формирања знања која су примењива у реалном животном контексту. Предложен ток реализације наставе доприноси развијању компетенција које надилазе предметне садржаје, по- 
пут аналитичког и критичког мишљења, рада у тиму, вештине комуникације, презентације, вођења дискусије, давања и примања повратне информације и преузимања одговорности. Млади који уче на овакав начин моћи ће лакше да се суоче са изазовима савремених друштвених токова и развију неопходан ниво резилијентности. Међутим, залагање за промену приступа не мора нужно да резултира значајним и широко прихваћеним променама у пракси, односно у начину на који школе заправо организују и пружају искуство учења ученицима. Зато се фокус иницијалног образовања и континуираног стручног усавршавања наставника помера са позиције у којој је наставник стручњак за предмет, ка позицији у којој је наставник стручњак за учење. На тај начин се даје предност побољшању квалитета образовања и изградњи капацитета наставника како би могли директно да утичу на развој међупредметних компетенција ученика (Riviou 2014).

\section{ПРОЈЕКТНА НАСТАВА КАО РЕСУРС ЗА РАЗВИЈАЮЕ МЕЂУПРЕДМЕТНИХ КОМПЕТЕНЦИЈА}

Пројектна настава своју теоријску основу заснива на принципу подстицања критичког мишљења, комуникације, сарадње и креативности ${ }^{5}$ (Scott 2015). Сходно томе, наставни пројекти су по својој природи комплексни, интердисциплинарни, тимски оријентисани, укључују коришћење различитих активности и интеракција које прате логички след истраживачких процедура, од постављања проблема, циљева и хипотеза, преко израде пројекта, до његове реализације и представљања резултата и настоје да код ученика побољшају креативност, иновативност и предузетништво (Hanney, Savin-Baden 2013). Из тих разлога се пројектна настава идентификује као популаран и ефикасан модел за развијање кључних, а нарочито међупредметних компетенција (Ravitz et al. 2012), а међупредметне компетенције се разумеју као стуб процеса пројектне наставе (Петровић, Хоти 2020). У прилог томе говори и велики број емпиријских истраживања која испитују ефекте пројектне наставе, а једно од њих је метасинтеза осам метаанализа и истраживачких прегледа у којима су упоређивани ефекти пројектне и традиционалне, предавачке наставе (Strobel, Van Barneveld 2009). Резултати ове метасинтезе показали су да се пројектном наставом постижу позитивнији ефекти у погледу трајности и квалитета знања (утврђено је дугорочније памћење садржаја, од дванаест недеља до две године након рада на пројекту, као и развијање трансферних знања). Истраживања такође упућују на то да се применом пројектне наставе: а) подиже ниво појмовне анализе, разумевања принципа, удубљивања у материју и критичког

${ }^{5}$ У литератури на енглеском језику овај принцип је познат под називом „4С”- critical thinking, communication, cooperation and creativity. 
размишљања; б) научени подаци дуже памте јер се обрађују другачије него када се користи рецептивно учење; в) прибегава делотворним стратегијама решавања проблема и успешно савладавају различите академске дисциплине; г) развијају способности решавања проблема али и концептуалне вештине значајне за радно окружење XXI века; д) ученици оспособљавају за рад са технологијама XXI века; ђ) постижу добри резултати у раду са ученицима нижег образовног постигнућа и проблемима у учењу (Бендер 2020).

Пројектна настава је својеврстан хибридни модел који обједињује проблемску и истраживачку наставу. С обзиром на карактеристике и структуру активности, њена рефлексивност може бити веома лако и брзо видљива на плану развијености међупредметних компетенција ученика. Једна од полазних активности на којима се заснивају израда пројекта и истраживачки процес јесте формулисање и решавање проблемских истраживачких питања и задатака. Заједнички рад ученика на тражењу одговора на проблемско истраживачко питање има функцију усвајања кључних научних појмова. Формулисање доброг питања није једноставан задатак па је ученицима неопходно објаснити да се у овој активности руководе следећим смерницама: а) да би се добио одговор на проблемско питање, могуће је направити пројекат и на основу њега реализовати истраживање; б) ресурси и материјали неопходни за спровођење истраживања су лако доступни; в) могуће је извршити декомпозицију проблема, поделити га на уже проблеме (Marx et al. 1997). Ученици се путем различитих сценарија подстичу да анализирају или откривају проблемске ситуације, и тиме се у први план ставља развој критичког мишљења, креативних способности решавања проблема, али и управљања сопственим учењем.

Истраживања показују да изазовне проблемске ситуације често покрећу снажне емоционалне реакције ученика (Allison et al. 2015). Да би превазишли ове реакције, ученици развијају стратегије решавања проблема и особине као што су самопоуздање и резилијентност, битне за развој одговорног односа према здрављу. Ако се узме у обзир схватање да се у савременом друштву здравље сагледава на холистички начин, и не подразумева само физичко, већ и ментално, емоционално и социјално здравље, школе би требало деци и младима да пруже што више могућности за вођење здравог и активног начина живота. Добро здравље обликују начини на које култура и животна средина промовишу развој емоционалних, социјалних и менталних вештина, неопходних за успех у учењу и у животу. Развој емоционалних вештина, на пример, омогућава деци и младима да разумеју, доживе и изразе различите емоције и подстичу их да доносе одлуке и да се носе са стресом. Социјалне вештине укључују комуникацију и емпатију, које омогућавају појединцу да развија међуљудске односе, комуницира са другима, дискутује о својим и туђим идејама и доприноси демократским процесима. Менталне вештине укључују решавање проблема, критичко размишљање и креативност и захва- 
љујући њима појединци су отворени за нове идеје, траже изазове и мотивисани су да прошире своја знања. Стога су изазовне проблемске ситуације у пројектној настави неопходан услов за емоционално и социјално учење које можда није тако лако поновити у уобичајеној настави, где је преузимање ризика сведено на минимум како би се осигурало да ученици достигну формалне исходе учења (Allison et al. 2015).

У наредним корацима ученици путем истраживања имплементирају своје идеје и планове за решавање проблемског питања, спроводе различита теренска истраживања и презентују добијене резултате. Након формулисања проблемског истраживачког питања следи израда пројекта истраживања планирање истраживачких процедура, одређивање временске динамике истраживања, начина његовог спровођења, обраде добијених података и обезбеђивање неопходних ресурса. У овом кораку задатак наставника је да ученике оспособи да добро дефинишу хипотезе и објасне поступке које намеравају да примене у истраживању. Постављање сопствених хипотеза је значајна активност која подстиче ученике на систематско коришћење постојећих знања и критичко процењивање интуитивних концепата. Следећи корак подразумева спровођење истраживања и прикупљање и обраду података. Ученици могу да спроведу почетно истраживање у учионици, користећи доступну литературу и онлајн ресурсе, али се потенцира проширивање окружења за учење и прикупљање информација у ширем контексту - организовањем истраживања ван школе (Habok, Nagy 2016). Истраживања ван уобичајеног школског контекста тесно су повезана са развијањем одговорног односа према околини. Један од примера пројеката таквог типа је међународни програм $G L O B E$ који има за циљ укључивање ученика у различита мерења и опажања у непосредном природном окружењу школе, и тиме доприноси бољем и потпунијем разумевању еколошких односа и промена у глобалном окружењу. На пример, ученици путем пројектних активности треба да истраже узроке и последице проблема појаве тзв. топлотних острва, и покушају да одговоре на питање „Зашто је температура ваздуха у граду просечно већа него у околини?” (Ристановић, Банђур, 2020). Сређивање података добијених истраживањем важан је корак у пројектној настави јер представља пут од практично-опажајног ка логичком мишљењу и подстиче развијање међупредметне компетенције pag c йоgацима и информацијама. Приликом сређивања података од чињеница се прелази на размишљање и закључивање о њима, а нарочито се укључују мисаоне операције као што су анализа, компарација, идентификовање, класификација и апстракција (Ристановић 2019). Резултате пројектног истраживања потребно је представити ширем аудиторијуму (члановима одељења, школе, родитељима, локалној заједници и сл.) коришћењем различитих медија као што су постери, блогови, видео-записи и др.

Сваки од наведених корака (Ристановић, Стојановић, Живковић 2018; Ристановић 2019) укључује висок ниво партиципације ученика уз помоћ и 
подршку наставника, а посебно вредним сматра се остваривање сарадње између ученика, али и партнерства школе са родитељима и широм заједницом (Поповић 2017, Поповић, Зуковић 2014). Резултати експерименталног истраживања указују на то да пројектне активности значајније подстичу развој сарадничког понашања ученика у групама у односу на групне активности у традиционалном моделу наставе (Ристановић 2019). Пројектни рад делује на успостављање позитивне међузависности ученика у групи, унутаргрупну комуникацију и отвореност за решавање проблема, што углавном није случај у настави која се заснива на уобичајеним групним активностима. Идентификовани обрасци сарадничког понашања довели су до закључка да се ученици у пројектним активностима чвршће окупљају око заједничког циља и активности које су у функцији његове реализације.

Док раде у групи, хомогеној или хетерогеној (Шефер 2005), користећи одређене информације, ученици учествују и сарађују како би дошли до адекватног решења, одговорно комуницирају поштујући права осталих чланова групе, што се рефлектује и на развијање предузимљивости и оријентацији ка предузетништву. Школски пројекти усмерени на развијање предузетничке компетенције имају за циљ да ученици, посебно средњошколског узраста, стварају виртуелна мини-предузећа и њима управљају више од годину дана. На тај начин уче о различитим занимањима, специфичностима одређених привредних грана, сарађују са професионалцима из пословног света и подижу свест о могућностима развијања сопствене каријере у глобалном окружењy (Arjomand et al. 2013).

На крају треба споменути и потребу и могућност пројектне наставе у развоју дигиталне компетенције. Стицање и развијање дигиталне компетенције сматра се једним од императива образовања у XXI веку и постаје све важнија за општу писменост (Ристановић, Банђур 2020). Захваљујући брзом ширењу дигиталних технологија, код ученика се променио начин размишљања, прикупљања и обраде информација, што им отежава учешће у систему формалног образовања у којем и даље доминирају застареле наставне методе (Autry, Berge 2011). Младима је неопходно иновативније окружење за учење фокусирано на отворене задатке проблемског типа који се могу решавати у тимовима, и уз помоћ дигиталне технологије. Технолошки производи попут рачунара и мобилних телефона информације обрађују тренутно, и ученици прилагођавају своје могућности да раде и играју се брзим темпом. Навикли су да примају информације из мултимедијских извора па им је без континуиране информацијске стимулације често досадно и нису у стању да се лако концентришу. Другим речима, деци која су одрасла у свету засићеном дигиталним медијима, пажњу у школи могуће је одржати уколико је средина за учење обогаћена медијима (Prensky 2001). У складу са тим, савремени приступ пројектној настави све чешће се односи на коришћење технолошки заснованог окружења, најчешће у виду рачунарских мрежа и дигиталних ала- 
та који могу да обезбеде ефикасно учење. Наставник и ученици могу да буду у виртуелној учионици, односно да контактирају иако су физички удаљени. Такви простори су отворени за веће и различите групе, а ученици имају прилику да упоређују сопствене и туђе пројекте. Што је најважније, интернет може да буде коришћен као средство комуникације и сарадње, односно да створи дуге и трајне дијалоге између ученика - аутора пројеката и њихове публике (Ристановић, Банђур 2020). Коришћем одговарајућих алата, као што су алати засновани на клауду (облаку), дигиталне учионице, дигиталне огласне табле, софтвери за управљање пројектима и многих других (Boss, Larmer 2018), у процесима мапирања, визуелизовања и размене идеја, планирања пројектних активности, прикупљања и анализе података, представљања пројектних резултата и континуиране сарадње, очекује се да ће се повећати дигитална компетентност ученика.

\section{ЗАКЉУЧАК}

Развијање међупредметних компетенција, у Србији дефинисаних Законом о основама система образовања и васпитања (2017), један је од кључних задатака школе. Иако се о њима говори као о вештинама за XXI век, оне су одувек биле важне, али се сада у већој мери истиче значај њиховог развијања кроз све нивое формалног образовања. Пројектна настава пружа идеалну прилику да се њихово стицање, развијање и континуирано усавршавање свеобухватније укључи школски систем. Рад на пројектима се препоручује и врло успешно користи као водећи приступ у којем ученик има прилику да самостално бира активности, методе рада и средства која по његовом мишљењу најбоље доприносе постизању унапред постављеног циља (Matijević 2009). С друге стране, уколико ради у групи, на пројекту са сложенијим задацима, ученик се навикава на тимски рад, помагање, дељење и сараднички однос, на истраживачку оријентацију у учењу и раду, а притом искуство и усвојена знања ставља у службу трагања за новим сазнавањима (Polman 1998). Додатна предност пројектне наставе, која доприноси ефикасности развијања кључних, предметних и међупредметних компетенција јесте правовремена повратна информација, која служи да ученик сазна да ли је на добром путу до остварења циља. Такође, ученик јасније сагледава практичну вредност свог знања и искуства, учи на које начине може доћи до извора сазнања, професионално се усмерава, развија предузимљивост и припрема се за активно учешће у предузетничким процесима. Педагошке импликације овог рада садржане су у истакнутим вредностима пројектне наставе и представљају својеврстан позив за њену озбиљнију примену у наставној пракси. 


\section{ЛИТЕРАТУРА}

Allison et al. (2015): P. Allison, S. Gray, R. Martindale, C. Nash, J. Sproule, J. Wang, 2015, Exploring Contributions of ProjectBased Learning to Health and Wellbeing in Secondary Education, Improving Schools, 18/3, 207-220.

Arjomand et al. (2013): G. Arjomand, O. Erstad, O. Gilje, J. Gordon, V. Kallunki, C. Kearney, O. Rey, A. Siewiorek, M. Vivitsou, J. von Reis Saari, KeyCoNet 2013 Literature Review: Key Competence Development in School Education in Europe, Brussels: European Schoolnet.

Autry, Berge (2011): A. J. Autry, Z. Berge, Digital natives and digital immigrants: getting to know each other, Industrial and commercial training, 43/7, 460-466.

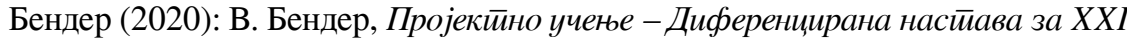
век, Београд - Јагодина: Clio - Факултет педагошких наука.

Boss, Larmer (2018): S. Boss, J. Larmer, Project Based Teaching: How to Create Rigorous and Engaging Learning Experience, Novato, CA: Buck Institute of Education.

Burke (2005): W. J. Burke, Competency Based Education and Training, London: Routledge.

Dart, Drake (1995): P. Dart, L. Drake, Mentors in English and mathematics. In Reid I., Constable, H. and Griffiths, R. (Eds): Teacher Education Reform, London: Paul Chapman.

Evropska komisija / EACEA / Eurydice (2012): Developing Key Competences at School in Europe: Challenges and Opportunities for Policy. Eurydice Report, Luksemburg: Ured za publikacije Europske unije.

Закон о основама система образовања и васпитања Републике Србије (2017), Службени ілласник РС, бр. 88.

Freire (2001): P. Freire, Pedagogy of freedom ethics, democracy and civil courage, Lanham, MD: Rowman \& Littlefield Publisher.

Marx et al. (1997): R. W. Marx, P. C. Blumenfeld, J. S. Krajcik, E. Soloway, Enacting project-based science: Challenges for practice and policy, Elementary School Journal, 97, 341-358.

Matijević (2008): M. Matijević, Projektno učenje i nastava, Nastavnički suputnik, Boris Drndarić (ur.), Zagreb: Znamen, 188-225.

Pellegrino, Hilton (2012): J. W. Pellegrino, M. L. Hilton (eds.), Education for Life and Work: Developing Transferable Knowledge and Skills in the 21st Century, Committee on Defining Deeper Learning and 21st Century Skills, James W. Pellegrino and Margaret L. Hilton, (eds.), Board on Testing and Assessment and Board on Science Education, Division of Behavioral and Social Sciences and Education, Washington, DC: The National Academies Press.

Петровић, Хоти (2020): М. Петровић, Д. Хоти, Приручник за йројекӣну насйаву и насйаву на gаљину. https://jpd.rs/images/preuzmite/Prirucnik_za_nastavu.pdf

Поповић, Зуковић (2014): Д. Поповић, С. Зуковић, Партнерство породице и

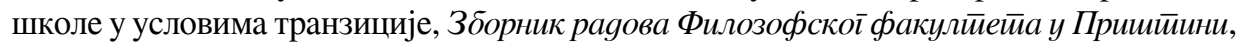
44/1, 219-235.

Поповић (2017): Д. Поповић, Партнерско деловање у функцији просоцијалног

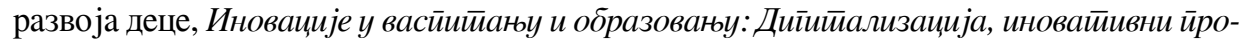
ірами и моgели, Лепосавић: Учитељски факултет у Призрену, 289-298. 
Правилник о општим стандардима постигнућа за крај општег средњег образовања и средњег стручног образовања у делу општеобразовних предмета (2013): Службени илласник РС, бр. 117.

Prensky (2001): M. Prensky, Digital Natives, Digital Immigrants, Part 1, On the Horizon, 9/5, 1-6.

Polman (1998): J. Polman, Activity Structures for Project-based Teaching \& Learning: Design and Adaptation of Cultural Tools, San Diego: Annual Meeting of AERA: http:// www.cet.edu/pdf/tools.pdf.

Ravitz, Hixson, English, Mergendoller (2012): J. Ravitz, N. Hixson, M. English, J. Mergendoller, Using project based learning to teach 21st century skills: Findings from a statewide initiative (paper presented at the American Educational Research Association Conference, Vancouver, Canada).

Riviou (2014): K. Riviou, Cross-curricular project-based learning approach fostering competences. https:/www.ea.gr/ea/myfiles/File/presentations/_Cross-curricularProjectbasedLearningApproachFosteringCompetences.pdf

Ристановић, Банђур (2020): Д. Ристановић, В. Банђур, Теоријско-методолошке претпоставке развијања компетенција ученика путем пројектне наставе, Проірамске (ре)форме у образовању и васииийану - изазови и йерсиеккиииве, Београд: Учитељски факултет, 375-384.

Ристановић (2019): Д. Ристановић, Пројекӣни моgел насйаве йрироgе и gрушимва, Јагодина: Факултет педагошких наука.

Слијепчевић, Зуковић (2015): С. Слијепчевић, С. Зуковић, Компетенције педагога у контексту 'друштва које учи', Зборник раяова Филозофской факулйейа у

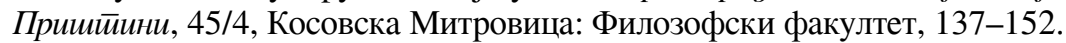

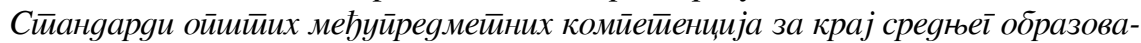
на (2013). Београд: Завод за вредновање квалитета образовања и васпитања.

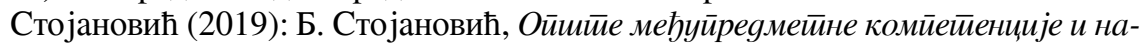
сйава и учене, Београд: Klett друштво за развој образовања.

Strobel, Van Barneveld (2009): J. Strobel, A. van Barneveld, When is PBL more effective? A meta-synthesis of meta-analyses comparing PBL to conventional classrooms, Interdisciplinary Journal of Problem-based Learning, 3(1), 43-58.

Scott (2015): C. L. Scott, The futures of learning 3: What kind of pedagogies for the 21st century?, UNESCO Education Research and Foresight, Paris [ERF Working Papers Series, 15].

Habok, Nagy (2016): A. Habok, J. Nagy, In-service teachers' perceptions of project-based learning, Springer Plus, 5:83

Hanney, Savin-Baden (2013): R. Hanney, M. Savin-Baden, The problem of projects: understanding the theoretical underpinnings of project-led PBL, London Review of Education, 11/1, 7-19.

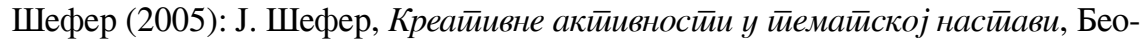
град: Институт за педагошка истраживања. 


\section{Daliborka R. Popović}

State University of Novi Pazar

Department of Philosophy

Dušan P. Ristanović

University of Kragujevac

Faculty of Education in Jagodina

Department of Didactics and Methodology

\section{POTENTIALS OF PROJECT-BASED LEARNING FOR THE DEVELOPMENT OF CROSS-CURRICULAR COMPETENCES}

Summary: One of the key goals of modern educational policies is the need to develop students' abilities that will enable them to function in conditions of dynamic social and technological changes. A necessary condition for achieving such a defined goal is to abandon the traditional, transmission approach to teaching and learning and to introduce a more engaged process of knowledge construction in a real life environment. A different approach to teaching and learning implies a comprehensive reform of the educational system, which should take place in two key directions. The first refers to curricular reform, to the introduction of a curriculum oriented towards the acquisition and development of key competencies for lifelong learning and, in particular, cross-curricular competencies. The second direction is focused on the consideration and application of various teaching strategies and models in school practice, which support this concept. Considering that project-based learning has recently been introduced into our school system as a mandatory model of work, the aim of this paper is to present its most important possibilities for developing students' cross-curricular competencies.

The paper starts with an overview of eight key competencies for lifelong learning defined by the European Commission, which have been included in the educational system of the Republic of Serbia since 2017. Following this, the necessity and importance of developing cross-curricular competencies for students were singled out and presented, and then the emphasis was put on the analysis of the possibilities that project teaching can provide in that process. The conclusion emphasizes the values of project-based learning and benefits for students and teachers, as well as for the society as a whole; important pedagogical implications can be drawn, as they represent a kind of invitation to teachers for more serious application of project-based learning in school practice.

Keywords: key competences for lifelong learning, cross-curricular competences, project-based learning. 